\title{
Analisis Kinerja Saham Syariah Dan \\ Pengaruhnya Terhadap Respon Pasar \\ Pada Perusahaan Yang Tercatat di Jakarta Islamic Indeks
}

\section{Ratna Utami, Maha Putra Kusuma Nugraha}

\author{
Fakultas Ekonomi \& Bisnis Universitas Muhammadiyah Malang \\ Jl. Raya Tlogomas 246 Malang, Jawa Timur \\ Email: ratna_ermadi@yahoo.co.id
}

\begin{abstract}
Abstrak
The purposes for this research to describe performance stock of sharia and its influence on market response to the companies listed on the Jakarta Islamic Index (JII). In this research, researchers will describe the condition of the stock performance of sharia with approach the rate of return and risk. The population of research is Islamic stocks listed in the JII for the period December 2008-November 2010 and sampled in this study a total of 17 issuers of sharia using purposive sampling. The unit of analysis in the research is the performance of the stock by using the excess return and excess return to beta ratio, rate of return based on expected return and risk (beta). For to see the effect in response to market, units of analysis used is technical analysis with approach to stock trading volume and high and lows, as well as using non-parametric analysis to see how investors choise stocks sharia evenly. The result of study show total of 17 issuers provide the return on stocks is positive. Excess return, there are 16 competent stock to be invested and based on counting of excess return to beta, 16 sharia stocks is good to invested and has good performance. Islamic stock performance in Jakarta Islamic Index has an influence on the market response is significantly.
\end{abstract}

Keywords: Stock Performance on JII, Returns and Risk, Market Response.

\section{PENDAHULUAN}

Perkembangan reksadana syariah saat ini memiliki pengaruh yang cukup besar terhadap pertumbuhan sistem ekonomi berbasis Islam di Indonesia, dimana sistem ini menerapakan tatanan perekonomian yang tidak bertentangan dengan hukumhukum Islam atau yang lebih dikenal dengan saham syariah, hal ini menjadi fenomena yang menarik dan menggembirakan terutama bagi penduduk Indonesia yang mayoritas beragama Islam. Menariknya adalah selama ini aktivitas investasi di pasar modal Indonesia telah berjalan selama berpuluh-puluh tahun dengan menggunakan sistem konvensional. Kehadiran investasi syari'ah pada akhirnya akan memberikan warna tersendiri dan memunculkan dampak kompetitif diantara keduanya. Selain itu dengan adanya investasi syari'ah akan menjadi angin segar atau pun kabar gembira bagi penduduk muslim Indonesia yang ingin berinvestasi tanpa harus diliputi rasa takut atas kehalalan proses investasi karena semua aktivitas tersebut telah disesuaikan dengan aturan-aturan agama yang bersifat syar'i dan tetap berada pada koridor ajaran agama Islam.

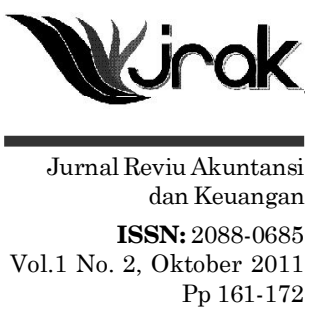




\section{Analisis \\ Kinerja Saham Syariah...}

162
Selama ini indeks Islam atau indeks syari'ah telah banyak membantu institusi untuk menginvestasikan kelebihan dananya di investasi yang sesuai dengan syariah. Indeks tersebut dikeluarkan oleh Bursa Efek Jakarta (yang kini telah menjadi Bursa Efek Indonesia). Sedangkan aktivitas jual-beli saham syari'ah dilakukan di Jakarta Islamic Indeks (JII). Berikut mekanisme sederhana terkait dengan aktivitas investasi di JII (Kurniawan, 2000):

"Di dalam JII ada 30 Emiten yang masuk perhitungan, yang dievaluasi setiap 6 bulan. Penentuan komponen Indeks setiap bulan Januari dan Juli. JII mensyaratkan saham dengan jenis usaha utama yang tidak bertentangan dengan prinsip syariah dan sudah tercatat lebih dari tiga bulan kecuali termasuk dalam 10 kapitalisasi besar. Pemilihan saham berdasarkan laporan keuangan tahunan atau tengah tahun berakhir yang memiliki rasio kewajiban terhadap aktiva maksimal sebesar $90 \%$. Selanjutnya 60 saham dari susunan saham diatas berdasarkan urutan rata-rata kapitalisasi pasar terbesar selama satu tahun terakhir. JII juga memilih 30 saham dengan urutan berdasarkan tingkat likuiditas rata-rata nilai perdagangan regular selama satu tahun terakhir".

Banyak terjadi isu pertentangan mengenai keberadaaan saham syari'ah setelah munculnya perdagangan saham syari'ah, hal ini dipicu dengan adanya anggapan bahwa harga saham memiliki kecenderungan untuk lebih berfluktuatif, sehingga dapat menimbulkan spekulasi dalam jual-beli saham. Ketidakwajaran dalam fluktuatif harga saham dapat disebabkan oleh beberapa faktor, Seperti yang dinyatakan oleh Chapra dalam Achsien (2003) yaitu spekulasi didukung dengan margin trading. Spekulasi dapat dikontraskan secara tajam dengan true investor dalam bursa efek dalam beberapa hal. Investor dapat melakukan pembayaran sepenuhnya, jadi tidak sekedar melakukan margin trading. Sementara Obaidullah dalam Achsien (2003) menyikapi margin trading yang mendorong spekulasi itu lebih baik perlu adanya kebijakkan minimum holding period. Sehingga, margin trading dapat diminimaliskan dan tingkat spekulasi pun kecil.

Melihat hal tersebut para pakar ekonomi Islam banyak memberikan wacana mengenai suatu revolusi atau inovasi terhadap saham syari'ah, dimana saham syari'ah merupakan penyertaan yang merefleksikan kepemilikan perusahaan bukan partnership pribadi dan hal ini sudah diterima secara luas oleh pelaku pasar. Saham syari'ah secara harfiah merupakan surat berharga yang merepresentasikan penyertaan modal kedalam suatu perusahaan. Sementara dalam prinsip syari'ah, penyertaan modal dilakukan pada perusahaan-perusahaan yang tidak melanggar prinsip-prinsip syari'ah, seperti bidang perjudian, riba, memproduksi barang yang diharamkan seperti bir, dan lain-lain.

Peran pasar modal sebagai wahana alternatif bagi investor dipengaruhi oleh banyak faktor. Salah satu faktor yang menentukan menurut Bawazier dan Sitanggang (1994) adalah tingkat kemampuan investor memilih saham secara rasional. Rasionalitas investor dapat diukur dari sejauh mana mereka berhasil memilih saham yang memberi hasil maksimum pada risiko tertentu, juga dipengaruhi oleh preferensi investor terhadap return dan risiko yang berbeda. Investor akan selalu mencoba mencari portofolio yang memberikan return maksimum dengan risiko tertentu, atau return tertentu dengan risiko minimum. Tetapi, pada kenyataannya investor sering melakukan diversifikasi dalam investasinya. Mereka mengkombinasikan berbagai sekuritas dalam investasi mereka. Investor melakukan diversifikasi ini untuk mengurangi risiko.

Poon dan Ward (1992) melalui studi empirisnya dengan menggunakan analisis pictorial, menarik kesimpulan bahwa diversifikasi saham melalui simulasi mampu memperkecil tingkat risiko dan mencapai return maksimal. Uji coba dilakukan dengan menggunakan 10, 25, 50 sampai 100 saham untuk membentuk portofolio. Sedangkan Bringham dan Gapenski (1993) memilih portofolio efisien dari portofolio yang terletak pada efficient frontier, Untuk menganalisis portofolio, diperlukan sejumlah prosedur perhitungan melalui sejumlah data sebagai input tentang struk- 
tur portofolio. Struktur portofolio yang optimal akan berpengaruh terhadap perkembangan respon pelaku pasar terhadap kinerja saham secara signifikan (Rifqiawan, 2008). Hal ini merupakan merupakan fenomena yang wajar, karena hal tersebut merupakan suatu indikator utama dalam melihat sejauh mana kepuasan para investor pada portofolio optimal, dimana aspek fundamental dan teknikal merupakan salah satu faktor penting yang dijadikan pertimbangan oleh para investor, dalam mengambil keputusan.

Selama tiga tahun terakhir 2007-2009, pelaku pasar di BEI memiliki respon yang cukup positif terhadap indeks JII. Salah satu faktor penting yang dijadikan pertimbangan oleh para investor adalah aspek fundamental saham JII dinilai sangat baik dan konsisten pertumbuhannya. Kinerja saat ini (current performance) dari 30 anggota JII secara komposit menunjukkan financial result di atas rerata 82 sampel saham BEI. Begitu pula, prospek bisnis emiten JII diprediksi pelaku pasar modal memiliki peluang tumbuh di masa depan yang lebih baik dibandingkan rerata industri. Hal tersebut didukung oleh penelitian Nadhifa (2011) yang menyatakan bahwa pada tahun 2009-2010 terdapat 19 emiten JII yang memberikan tingkat pengembalian saham bernilai positif dan terdapat 13 saham syari'ah merupakan saham agresif yang sensitif terhadap perubahan pasar. Berdasarkan penghitungan excess return, terdapat 11 saham yang layak untuk diinvestasikan dan berdasarkan penghitungan excess return to beta ratio, terdapat 11 saham syariah yang layak diinvestasikan serta memiliki kinerja yang baik.

Hal ini berbanding terbalik dengan penelitian (Harahap, 2009). yang menyatakan bahwa secara keseluruhan saham-saham syariah periode Januari-Mei 2008 tidak menguntungkan karena tingkat pengembalian pasar lebih kecil dari tingkat pengembalian bebas risiko dan hanya terdapat 8 saham yang menguntungkan dari 30 saham syariah yang terdaftar dalam JII.

Berangkat dari uraian diatas peneliti ingin melakukan pengkajian lebih mendalam mengenai tingkat kinerja saham syariah dan bagaimana responnya terhadap pasar pada emiten yang tercatat di JII (Jakarta Islamic Indeks). Berdasarkan penjelasan sebelumnya peneliti masih melihat adanya permasalahan yang muncul mengenai isu dimana respon pasar terhadap saham syariah pada tahun 20072009 menunjukkan trend yang cukup positif dengan memberikan tingkat pengembalian yang positif pula, hal tersebut didukung dengan pernyataan yang menyatakan bahwa kinerja saham syariah pada tahun 2009-2010 memberikan tingkat pengembalian yang baik (Nadhifa, 2011). Namun peneliti melihat hal tersebut bertolak belakang dengan penelitian yang menyatakan bahwa saham JII (Jakarta Islamic Indeks) pada tahun 2008 tidak layak diinvestaikan, karena saham syariah dinilai memberikan tingkat pengembalian yang kecil (Harahap, 2009).

\section{METODE}

Jenis penelitian yang dilakukan oleh peneliti adalah deskriptif, yaitu peneliti melakukan kajian atas analisis suatu objek penelitian sehingga dapat menggambarkan kondisi dari objek penelitian. Pada penelitian ini, peneliti akan menggambarkan kondisi kinerja saham syariah dengan pendekatan tingkat pengembalian dan risiko.

Populasi yang digunakan dalam penelitian ini adalah saham-saham syariah yang tercatat dalam JII untuk periode Desember 2008-November 2010. Teknik pengambilan sampel yang dilakukan peneliti adalah metode purposive sampling. Karakteristik purposive sampling perusahaan yang dipilih berdasarkan judgment sampling peneliti, yaitu perusahaan yang tercatat di Jakarta Islamic Indeks dan perusahaan yang paling konsisten di Jakarta Islamic Indeks selama periode Desember 2008-November 2010.

Data yang digunakan dalam penelitian ini meliputi:

a. Harga penutupan bulanan harga saham dari bulan Desember 2008-November 2010 
Analisis

Kinerja

Saham

Syariah...

164

b. Tingkat SBI bulan Desember 2008-November 2010

c. Data mengenai pembagian dividen, stock split, dan profil emiten yang terdaftar di JII periode Desember 2008-November 2010

\section{Unit Analisis}

1. Kinerja saham; Kinerja saham dinilai dengan Excess return dan Excess return to beta ratio.

2. Excess return; penilaian layak atau tidaknya suatu saham untuk di investasikan. Excess return ditentukan dengan mencari nilai selisih antara expected return saham dengan required rate of rate.

Rumus yang digunakan adalah:

$E R=E(R i)-R R R$

Keterangan:

ER : Excess return saham

$\mathrm{E}(\mathrm{Ri}) \quad$ : Expected return atas saham $\mathrm{i}$

RRR : Required Rate of Return

Required rate of return; Adalah tingkat pengembalian yang disyaratkan atas suatu investasi, diperoleh dengan menjumlahkan tingkat pengembalian dari investasi bebas risiko dengan premium atau kompensasi karena kesediaan investor menanggu risiko yang besar.

Risk Free Rate (Rf); Adalah tingkat pengembalian bebas risiko. Peneliti menggunakan tingkat SBI bulanan sebagai risk free rate.

3. Expected Return (Tingkat Pengembalian saham); tingkat pengembalian saham yang diharapkan oleh investor dalam periode tertentu (masa yang akan datang).

4. Risiko; Ukuran risiko yang digunakan adalah beta dihitung dengan membagi covarian antara saham dan pasar kemudian dibagi dengan varian pasar.

5. High and Lows; Menggambarkan kondisi pasar atau harga saham akan mengalami kenaikan (bearish).

6. Volume Perdagangan; Menggambarkan kondisi pasar semakin meningkat dibarengi dengan naiknya harga saham (bullish).

\section{Teknik Analisis Data}

Dalam menganalisis permasalahan yang ada, analisis data merupakan bagian yang terpenting dari penelitian karena dapat memberikan arti dan makna dalam pemecahan masalah. Metode yang digunakan untuk menghitung variabel pasar dan saham adalah model indeks tunggal, langkah-langkah yang dilakukan sebagai berikut:

a. Mengukur kinerja saham syari'ah

1) Menghitung parameter pasar

a) Return of market (Tingkat pengembalian pasar)

$$
R_{m}=\frac{I J I I_{t}-I J I I_{t-1}}{I J I I_{t-1}}
$$

\section{Keterangan}

$R_{m} \quad$ : Tingkat keuntungan pasar

$I_{t} \quad$ : Indeks JII periode $\mathrm{t}$

$I_{I I I} \quad$ : indeks JII sebelum periode $\mathrm{t}$ 
b) Expected return of market (Tingkat pengembalian pasar yang diharapkan)

$\mathrm{E}\left(R_{m}\right)=\frac{\sum\left(R_{m}\right)}{n}$

c) Varian pasar $\left(\sigma_{m}{ }^{2}\right)$

$$
\sigma_{m}{ }^{2}=\sum_{t=1}^{n}\left[\left(R_{m}-E\left(R_{m}\right)\right]^{2}\right.
$$

d) Standar deviasi $\left(\sigma_{m}{ }^{2}\right)$

$\sigma_{m}=\sqrt{\sigma_{m}^{2}}$

2) Menghitung parameter saham

a) Return saham (Tingkat pengembalian saham)

$R_{i}=\frac{P_{t}-P_{t-1}+D_{t}}{P_{t-1}}$

\section{Keterangan}

$\mathrm{Ri} \quad$ : Return saham sekuritas i

$\mathrm{P}_{\mathrm{t}} \quad$ : Harga saham pada saat ${ }_{t}$

$\mathrm{P}_{\mathrm{t}-1}$ : Harga saham pada saat ${ }_{\mathrm{t}-1}$

Dt : Dividen kas pada akhir periode

b) Expected return saham (Tingkat pengembalian saham yang diharapkan)

$$
\mathrm{E}\left(R_{i}\right)=\frac{\sum\left(R_{i}\right)}{n}
$$

c) Varian saham $\left(\sigma_{j}{ }^{2}\right)$

Adapun rumus beta sekuritas:

$\sigma_{j}^{2} \sum_{i=1}^{n}\left(\left[R_{i}-E\left(R_{i}\right)\right]^{2 \circ} P_{i}\right)$

Keterangan

$\sigma_{j}^{2}$ : Varian saham

$\mathrm{R}_{\mathrm{i}}$ : Return saham

Pi : Probabilitas saham

d) Standar deviasi $\left(\sigma_{j}\right)$

$$
\sigma_{j}=\sqrt{\sigma_{j}^{2}}
$$

e) Covarian

$$
\sigma_{i j}: \beta_{i} \cdot \beta_{j} \cdot \sigma_{m}{ }^{2}
$$

\section{Keterangan:}

$\sigma_{i j} \quad$ : Covarian return antar sekuritas $\mathrm{i}$ dan $\mathrm{j}$

$\beta_{i} \quad$ : Beta sekuritas i 


\section{Analisis \\ Kinerja \\ Saham \\ Syariah...}

166

Tabel 1:

Perhitungan Tingkat

Bunga SBI

Periode Desember

2008 - November

2010

$$
\begin{array}{ll}
\beta_{j} & : \text { Beta sekurtas } \mathrm{j} \\
\sigma_{m}{ }^{2} & : \text { varian dari return pasar }
\end{array}
$$

f) $\operatorname{Beta}\left(\sigma_{i}\right)$

Adapun rumus beta sekuritas:

$\beta_{i}=\frac{\sigma_{i} m}{\sigma m^{2}}$

Keterangan:

$\beta_{i}$ : Beta sekuritas

$\sigma_{i} m$ : Kovarian return antara sekuritas ke dengan return pasar

$\sigma m^{2}:$ varian return pasar

3) Menghitung kinerja saham dengan Excess return dan Excess return to beta ratio (Indeks Treynor)

4) Melihat respon pasar.

Menggunakan analisis teknikal dengan grafik, high and lows dan volume perdagangan. Karena alat anlisis lebih cocok digunakan untuk menilai respon pasar dibandingkan dengan indikator teknis lainnya.

5) Mengkomparasi excess return dengan analisis teknikal untuk melihat respon pasar.

6) Melakukan analisis dengan nonparametric test dengan pendekatan chisquare-test untuk melihat respon pasar.

\section{HASIL DAN PEMBAHASAN}

\section{A. Analisis Parameter Pasar}

Analisis parameter pasar digunakan untuk mengetahui kondisi pasar atau perkembangan harga saham yang dilihat dari perubahan indeks JII, apabila ratarata tingkat pengembalian pasar diatas tingkat pengembalian bebas risiko maka saham-saham syariah tersebut menguntung. Oleh karena itu, terlebih dahulu mengetahui berapa pengembalian bebas risiko untuk melengkapi analisis parameter pasar. Dalam analisis ini, penghitungan parameter pasar indeks JII menggunakan harga penutupan mingguan rata-rata indeks JII periode 28 November 2008 - 1 November 2010 dan untuk investasi bebas risiko menggunakan Tingkat SBI mingguan rata-rata periode 28 Desember 2008 - 1 November 2010. Berikut adalah tabel penghitungan tingkat bunga SBI dan hasil penghitungan parameter pasar, periode Desember 2008 - November 2010.

\begin{tabular}{lcc}
\hline Bulan & Minggu & SBI(\%)/Minggu \\
\hline Desember 2008 - Desember 2010 & I-IV & $\mathbf{6 . 5 0}$ \\
\hline TOTAL & & 650 \\
Rf/th(Desimal) & 0.065000 \\
Rf/mg(Desimal) & 0.000625 \\
\hline
\end{tabular}

\section{B. Analisis Parameter Saham}

Di dalam analisis parameter saham digunakan untuk mengetahui seberapa besar tingkat pengembalian yang diharapkan (expected return), variance, deviasi, covariance, RRR, dan beta dari masing-masing saham, sehingga berdasarkan hasil analisis pasar dan saham dapat digunakan dalam penghitungan excess return dan excess return to beta.

Berikut contoh penghitungan parameter saham pada salah satu emiten yaitu PT. Aneka Tambang (Persero) Tbk. periode Desember 2008-November 2010: 
$\mathrm{D}_{\mathrm{t}}=$ Dividen tunai (kas) yang diumumkan pada tahun 2009. Dividen tersebut harus di rata-rata kan terlebih dahulu karena dividen yang diumumkan merupakan dividen tahunan sedangkan dividen yang digunakan dalam penelitian ini adalah dividen mingguan, sehingga besarnya dividen tiap minggu sebesar

$$
\begin{aligned}
& D_{t(\text { mingguai) }}=\frac{D_{t(\text { diumumkdtahuna) }}}{N_{\text {mingguan }}}=\frac{R p .57}{100}=R p 1.16 / \text { minggu, maka } R_{i}=\frac{P_{t}-P_{t-1}+D_{t}}{P_{t-1}}= \\
& R_{i}=\frac{R p .960-R p .1020+R p .1 .16}{R p \cdot 1020}=-0.0577 .
\end{aligned}
$$

Kemudian, Dt=Dividen tunai (kas) yang diumumkan pada tahun 2010. Dividen tersebut harus di rata-rata kan terlebih dahulu karena dividen yang diumumkan merupakan dividen tahunan sedangkan dividen yang digunakan dalam penelitian ini adalah dividen mingguan, sehingga besarnya dividen tiap

$$
\begin{gathered}
\text { minggu sebesar } D_{t(\text { minggua) }}=\frac{D_{t(\text { diumumkdnahuna) }}}{N_{\text {mingguan }}}=\frac{R p 25}{100}=R p .0 .49 / \mathrm{minggu}, \text { maka } \\
R_{i}=\frac{P_{t}-P_{t-1}+D_{t}}{P_{t-1}}=R_{i}=\frac{R p .2175-R p .2250+R p .0 .49}{R p .2250}=-0.0331 .
\end{gathered}
$$

Hasil penghitungan tersebut menunjukkan bahwa PT. Aneka Tambang (Persero) Tbk. tidak memberikan keuntungan (loss) sebesar pada tahun 2009/ pada tahun 2010

$\mathrm{E}\left(R_{i}\right)=\frac{\sum\left(R_{i}\right)}{n-1}, \sum\left(R_{i}\right)=0.1520$, maka $\mathrm{E}\left(R_{i}\right)=\frac{-0.0577}{100}=0.0123$

Hasil penghitungan tersebut menunjukkan bahwa pengembalian yang diharapkan (Expected Return) yang diberikan oleh PT. Aneka Tambang (Persero) Tbk. 0.0123 .

$$
\begin{aligned}
& \sigma_{i}^{2}=\frac{\sum\left(R_{i}-E\left(R_{i}\right)\right)^{2}}{n-1}, \text { maka } \sigma_{i}{ }^{2}=\frac{(-0.0577-0.0123 \quad)^{2}}{100}=0.004898 \\
& \sigma_{i}=\sqrt{\sigma_{i}^{2}}, \text { maka } \sigma_{i}=\sqrt{0.004898}=-0.0700
\end{aligned}
$$

Hasil tersebut menunjukkan bahwa risiko total $\left(\sigma_{i}{ }^{2}\right)$ PT. Aneka Tambang (Persero) Tbk. sebesar 0.004898 sedangkan risiko saham individual tidak sistematis $\left(\sigma_{i}^{2}\right)$ sebesar -0.0700

$$
\begin{gathered}
\sigma_{i m}=\frac{E\left(R_{i}-E\left(R_{i}\right)\right)-\left(R_{m}-E\left(R_{m}\right)\right)}{n-1} \text {, maka } \\
\sigma_{i m}=\frac{(-0.0577-0.0123)-(-0.0326-0.0108)}{100}=0.0010
\end{gathered}
$$

Hasil tersebut menunjukkan bahwa kovarian antara risiko saham dengan risiko pasar bersifat negatif sebesar 0.0139 artinya pergerakan risiko saham searah dengan pergerakkan risiko pasar.

$$
\beta_{i}=\frac{\sigma_{i m}}{\sigma m^{2}}, \text { maka } \beta_{i}=\frac{0.0010}{0.0014}=0.7144
$$


Analisis

Kinerja

Saham

Syariah...

168
Hasil tersebut menunjukkan bahwa risiko sistematis $\left(\sigma_{i m}\right)$ PT. Aneka Tambang (Persero) Tbk. sebesar 0.7144 artinya saham PT. Aneka Tambang (Persero) Tbk. merupakan saham tidak agresif $\left(\sigma \mathrm{m}^{2}\right)$.

\section{Kinerja Portofolio Saham Berdasarkan Excess return to beta}

Bodie et al (2006) mendefinisikan excess return adalah tingkat imbal hasil yang melebihi tingkat imbal hasil bebas risiko. Dalam Warsono (2001) dijelaskan bahwa tingkat pengembalian bebas risiko adalah required rate of return yaitu tingkat pengembalian minimum yang akan diterima oleh investor dari suatu investasi sebagai pengganti kerugian karena penundaan konsumsi. Oleh karena itu dapat disimpulkan apabila saham memiliki excess return positif maka layak untuk diinvestasikan dan apabila saham memiliki excess return negatif maka saham tersebut tidak layak untuk diinvestasikan. Berdasarkan penghitungan excess return tersebut dapat diketahui bahwa terdapat 16 saham memiliki excess return bernilai positif dan 1 saham memiliki excess return bernilai negatif. Saham yang memiliki excess return tertinggi adalah Timah (Persero) Tbk (TINS) sebesar 0.0175 atau $1.75 \%$ dan saham yang memiliki excess return terendah adalah Telekomunikasi Indonesia (TLKM) sebesar -0.0047 atau $-0.47 \%$.

\section{Pengaruh Respon Pasar (Kondisi Pasar)}

Bedasarkan analisis teknikal terdapat pula 13 perusahaan yang dinilai memiliki respon pasar yang menurun atau buruk (bearish) yaitu, PT. Aneka Tambang (Persero) Tbk, PT. Astra International Tbk, PT. Global Mediacom Tbk, PT. Elnusa Tbk, PT. dilihat dari high and lows maupun volume perdagangan. Seperti PT. Global Mediacom Tbk, dilihat dari análisis teknikal (lampiran V), PT. Global Mediacom Tbk memiliki respon pasar yang sangat rendah (bearish), walaupun sempat mengalami kenaikan yang cukup drastis pada awal tahun 2009, tetapi pergerakan volume perdagangan maupun high and lows mengalami penurunan yang cukup drastis pada pertengahan tahun 2009.

\section{E. Mengkomparasi Hasil Perhitungan Excess Return Dengan Analisis Teknikal.}

Berdasarkan hasil komparasi kita lihat terdapat 13 perusahaan yang memiliki kinerja yang baik sedangkan respon pasarnya pada kondisi buruk atau menurun (bearish), dan 3 perusahaan yang memiliki kinerja baik dengan kondisi pasar baik (bullish) yaitu PT. Internasional Nickel Indonesia Tbk, PT. Indocement Tunggal Prakasa Tbk, PT. Unilever Indonesia Tbk, dan terdapat 1 perusahaan yang memiliki kinerja saham buruk dengan respon pasar yang baik (bullish) yaitu PT. Telekomunikasi Indonesia (Persero) Tbk. Dari hal tersebut dapat dilihat bahwa kinerja saham emiten dalam kondisi baik belum menjamin respon pasar baik (bullsih), begitu juga bila kondisi kinerja saham emiten buruk belum tentu menjamin respon pasar kondisi buruk juga atau bearish. Menurut Husnan (2003) respon pasar sendiri sebetulnya dipengaruhi oleh beberapa faktor fundamental yang tidak terikat langsung sebagai indikator untuk mengukur kinerja saham emiten, faktor tersebut adalah, seperti kebijakan pemerintah, pertumbuhan ekonomi, pertumbuhan penjualan perusahaan, pertumbuhan laba, perkembangan tingkat bunga, pertumbuhan ekonomi international, dan sebagainya.

\section{F. Analisis Non Parametrik}

Dilihat dari hasil perhitungan non parametrik terdapat dua bagian output. Pada bagian pertama output, terlihat ada Expected $\mathrm{N}$ atau volume perdagangan saham yang diharapakan terbeli. Oleh karena dipakai distribusi yang seragam, maka yang diharapkan sama rata, yaitu 217,2 (3692 dibagi 17 Excess Return saham emiten). Sedangkan kolom residual adalah selisih antara jumlah yang dibeli dengan jumlah yang diharapkan (seperti pada baris pertama adalah 15-217,2 = 202.2). 
a) Berdasarkan perbandingan chi square Uji danTabel:

Dilihat dari chi square bahwa chi quare hitung sebesar 4281.902 dimana

dalam kasus adalah kinerja saham, di dapat chi square tabel adalah 26.296

maka bahwa ho ditolak, karena Chi-Square hitung $>$ Chi-Square tabel.

b) Berdasarkan Probabilitas

Jika dilihat dari kolom Asym Sig/Asymtotic significance adalah 0.00 atau probabilitas dibawah $0.05(0.00<0.05)$ maka dapat disimpulkan bahwa ho diterima.

Dari hasil tersebut disimpulkan kinerja saham memiliki terhadap respon pasar walaupun tidak secara merata, atau lebih cenderung naik dan turun tetapi selalu memiliki kecenderungan untuk memilih saham syariah dilihat dari kinerja saham syariah sendiri.

\section{G. Pembahasan}

Berdasarkan hasil analisis yang telah dilakukan, peneliti dapat menggambarkan adanya kinerja saham - saham syariah yang tercatat di Jakarta Islamic Indeks cukup baik, dilihat dari perhitungan parameter pasar, parameter saham, excess return dan excess return to beta ratio. Dapat dibuktikan dengan adanya tingkat bunga mingguan rata - rata sebesar $0.625 \%$ dimana excpected return Jakarta Islamic Indeks lebih besar daripada tingkat pengembalian bebas resiko, selain itu dilihat dari portofolio optimal saham - saham di Jakarta Islamic Indeks memberikan tingkat pengembalian yang positif. Untuk excess return to beta ratio sendiri terdapat 16 perusahaan yang layak untuk diinvestasikan, dengan slope market risk/cut off point sebesar 0.096. Hal tersebut menggambarkan bahwa kinerja saham - saham yang tercatat di Jakarta Islamic Indeks cukup baik, dan hal tersebut mendukung penelitian yang dilakukan Nadhifa (2011) yang menyimpulkan bahwa saham-saham syariah pada periode 2009-2010 layak untuk diinvestasikan, sedangkan penelitian yang peneliti lakukan bertentangan dengan penelitian yang dilakukan Harahap (2009) dimana saham-saham syariah tidak menguntungkan bila diinvestasikan, hal ini disebabkan peneliti sebelumnya hanya mengukur kinerja saham syariah dalam satu periode saja, sedangkan saham syariah cenderung untuk berfluktuasi pada setiap periode, penelitian tersebut juga tidak mengukur resiko investasi saham-saham syariah sebagai salah satu pertimbangan dalam menentukan investasi.

Hal berhubungan secara langsung terhadap respon pasar, secara umum respon pasar sendiri dipengaruhi oleh beberapa faktor fundamental yang bersifat independent. Menurut Husnan (2003) respon pasar dipengaruhi oleh beberapa faktor yaitu, kebijakan pemerintah, pertumbuhan ekonomi, pertumbuhan penjualan perusahaan, pertumbuhan laba, perkembangan tingkat bunga, pertumbuhan ekonomi internasional, dan sebagainya yang dapat mempengaruhi respon pasar. Hal tersebut tidak mendukung dengan penelitian yang peneliti lakukan dimana peneliti menyimpulkan bahwa adanya pengaruh antara kinerja saham syariah dengan respon terhadap pasar, dilihat dari perhitungan nonparametrik yang dilakukan bahwa probabilitas pasar untuk memilih saham syariah berdasarkan kinerja saham syariah sangat signifikan. Selain itu dilihat dari hasil komparasi antara kinerja saham dan análisis teknikal, kinerja saham memiliki respon terhadap pasar walaupun cenderung untuk naik turun, atao positif dan negatif, walauupun ada sebagaian saham yang kinerjanya baik namun responnya negatif hal ini disebabkan karena fenomena sekarang ini investor lebih cenderung berspekulasi dalam memilih saham, atau margin traiding investor tidak melihat seberapa besar resiko yang akan diambil dalam menentukan untuk membeli saham.

\section{SIMPULAN}

Berdasarkan hasil penghitungan parameter pasar Jakarta Islamic Indeks periode Desember 2008 - November 2010, Indeks Jakarta Islamic Indeks 
Analisis

Kinerja

Saham

Syariah...

170

memberikan tingkat pengembalian pasar $(\mathrm{Rm})$ bernilai positif sebesar $0.108 \%$ dan lebih besar dari tingkat pengembalian investasi bebas risiko sebesar $0.625 \%$. Berdasarkan hasil penghitungan parameter saham Jakarta Islamic Indeks periode Desember 2008 - November 2010, terdapat 17 emiten saham syariah yang memberikan tingkat pengembalian saham (expected return) yang diharapkan bernilai positif.

Berdasarkan penghitungan excess return dan excess return to beta ratio, diketahui dari 17 saham syariah yang diteliti terdapat 16 saham yang layak untuk diinvestasikan. Saham-saham tersebut adalah Astra Argo Lestari Tbk, Aneka Tambang (Persero) Tbk, Astra International Tbk, Global Mediacom Tbk, Elnusa Tbk, Internasional Nickel Indonesia Tbk, Indocement Tunggal Prakasa Tbk, Indo Tambangraya Megah Tbk, Kalbe Farma Tbk, PP London Sumatra Tbk, Tambang Batu Bara Bukit Asam (Persero) Tbk, Sampoerna Argo Tbk, Semen Gresik (Persero) Tbk, Timah (Persero) Tbk, Bakrie Sumatera Plantations Tbk, Unilever Indonesia Tbk.

\section{DAFTAR PUSTAKA}

Achsien, I, H. 2000. Investasi Syariah di Pasar Modal. Gramedia. Jakarta.

Bawazier, S. dan Sitanggang. 1994. "Memilih Saham Untuk Portofolio Optimal". Usahawan. XI. pp. 34-40.

Brigham, E. F. and C. G. Louis. 1993. Intermediate Financial Management, edisi 4. The Dryden Press. New York.

Beaver. 1989. "Efficient Securities Market”, http://bandi.staff.fe.uns.ac.id. (diakses 7 April 2011)

Bodie, Z., A. Kane, and A.J. Markus. 2006. Investment. Edisi 6. The McGraw-Hill Company, Inc.USA

Fama. (1970), "Efficient Securities Market", http://bandi.staff.fe.uns.ac.id(diakses 7 April 2011)

Harahap, M.I. 2009. "Analisis Kinerja Saham Kategori Jakarta Islamic Index dengan pendekatan tingkat pengembalian dan risiko periode Januari-Mei 2008". Skripsi publikasi. Universitas Sumatera Utara.

Husnan, S. 2003. Dasar-Dasar Teori Portofolio dan Analisis Sekuritas,. Edisi Ketiga. UPP AMPYKPN. Yogyakarta.

Indah. (2011). "Analisis Pengaruh Rasio Likuiditas, Nilai Pasar \& Struktur Modal Terhadap Respon Pasar Pada Perusahaan LQ 45”. Skripsi Publikasi. Universitas Muhammadiyah Malang.

Info Reksadana Syariah. http://www.reksadanasyariah.net/ tanggal akses 1 Juli 2011

Jakarta Islamic Index. http://id.wikipedia.org tanggal akses 1 Juli 2011

Jogiyanto. 2000. Teori Portofolio dan Analisis Investasi. Edisi Ketiga. BPFE Yogyakarta. Yogyakarta.

Jones. 1995. "Efficient Securities Market", http://bandi.staff.fe.uns.ac.id (diakses tanggal 7 April 2011).

Kurniawan, T. 2008. Volatilitas Saham Syariah (Analisis Atas Jakarta Islamic Index), Karim Konsultan Review. Januari 2008. h.43.

Mursalin, A. 2010. "Analisis Perkembangan Investasi Syariah pada Pasar Modal Indonesia". Konstektualita volume 24. 1 april 2010.

Nadhifa, Nuraini. 2011. "Analisis Kinerja saham Syariah Dengan Pendekatan Tingkat Pengembalian dan Risiko Pada Perusahaan Yang Tercatat Di Jakarta Islamic Index (JII)". Skripsi publikasi. Universitas Muhammadiyah Malang.

Poon, S.J., C.W.R.Taylor, and Ward. Portfolio Diversivication: A Pictorial Analysis of the U.K. Stock Market.1992 
Rifqiawan, R.A. 2008. "Analisis Perbedaan Volume Perdagangan Saham-Saham Yang Optimal Pada Jakarta Isalmic Index (JII) Di Bursa efek Indonesia (BEI)”, Skripsi publikas. Universitas Diponegoro Semarang.

Setiawan, Aziz Budi. 2005. "Perkembangan Pasar Modal Syariah", Majalah Hidayatullah, Mei 2005.

Warsono. 2001. Analisis Investasi dan Manajemen Portofolio. UMM Press: Malang 
